\title{
Utilization of Aliphatic Amides and Nitriles by Nocardia rhodochrous LL100-21
}

\author{
By ELEANOR A. LINTON* AND CHRISTOPHER J. KNOWLES \\ Biological Laboratory, University of Kent, Canterbury, Kent CT2 $7 N J, U K$
}

(Received 2 December 1985; revised 31 January 1986)

\begin{abstract}
A wide range of nitriles and amides act as carbon and/or nitrogen sources for Nocardia rhodochrous LL100-21. Growth on a number of aliphatic nitriles or their corresponding amides resulted in the coinduction of both acetonitrile hydratase and acetamidase activities. In each case the specific activity of acetonitrile hydratase was higher than that of acetamidase. The substrate and inducer specificities were determined for the two enzymes and found to be quite distinct. Propionitrile, although an excellent inducer of both enzymes, was only slowly hydrolysed by acetonitrile hydratase. Conversely acrylonitrile was a good enzyme substrate but had a complete lack of effect as an inducer. Butyramide and methacrylamide acted as poor substrates for acetamidase but induced high levels of both acetonitrile hydratase and acetamidase. Dinitriles of long chain length, lactonitrile and iodoacetamide were inhibitory to growth and enzyme activity.
\end{abstract}

\section{INTRODUCTION}

Aliphatic nitriles are catabolized in two stages, via conversion to the corresponding amide and then to the acid plus ammonia by a nitrile hydratase and an amidase (acylamide amidohydrolase; EC 3.5.1 4) respectively (Arnaud et al., 1976a, b, 1977; Jallageas et al., 1978; DiGeronimo \& Antoine, 1976; Asano et al., 1980). Benzonitrile and related aromatic nitriles (Harper, 1976, 1977 a, b) and a heterocyclic nitrile (Robinson \& Hook, 1964; Hook \& Robinson, 1964) are converted directly to the corresponding acids and ammonia via a nitrilase (nitrile aminohydrolase; EC 3.5.5.1) with little formation of free amide and no separate requirement for amidase activity for production of acid.

Brevibacterium strain R312 utilizes aliphatic nitriles as sources of nitrogen for growth by using a constitutive nitrile hydratase possessing a wide substrate spectrum (Arnaud et al., 1976a, $b$, 1977) and a non-specific amidase (Jallageas et al., 1978). Pseudomonas aeruginosa and several other micro-organisms, although unable to catabolize aliphatic nitriles, form amidases that only utilize a small range of aliphatic amides (Clarke, 1980). Arthrobacter sp. J-1 utilizes aliphatic nitriles via an inducible nitrile hydratase and amidase (Asano et al., 1982). Nocardia rhodochrous LL100-21 can grow on a range of aliphatic nitriles and amides, as well as benzonitrile and benzamide as carbon and/or nitrogen sources (DiGeronimo \& Antoine, 1976; Collins \& Knowles, 1983). Studies of the enzyme activities suggest that the aliphatic nitriles and amides, and benzonitrile and benzamide are utilized by separate enzyme systems, which are inducible (Collins \& Knowles, 1983).

In the present study we have investigated the ability of a wide range of nitriles and amides to act as inducers, substrates and inhibitors of the aliphatic nitrile hydratase and amidase enzymes of $N$. rhodochrous LL100-21. Although these enzymes act on several nitriles and amides respectively, we have termed them, for convenience, acetonitrile hydratase and acetamidase. 


\section{METHODS}

Organism and growth conditions. Nocardia rhodochrous strain LL100-21 was grown on a minimal medium consisting of M-9 salts (Miller, 1972) with ammonium salts omitted, plus $1 \mathrm{ml}$ trace metals $1^{-1}$ (Bauchop \& Elsden, 1960 ) and a range of nitriles, amides and acids as carbon and nitrogen, carbon or nitrogen sources supplied at a concentration of 20,6 or $2 \mathrm{mM}$. Where indicated, the medium was supplemented with $10 \mathrm{mM}$-succinate as the source of carbon and/or 10 or $2 \mathrm{mM}-\mathrm{NH}_{4} \mathrm{Cl}$ as the source of nitrogen. A $2 \%(\mathrm{v} / \mathrm{v})$ inoculum of a $24 \mathrm{~h}$ stationary phase culture grown on the same carbon and nitrogen source as the experimental culture was used to inoculate the experimental flasks. Growth was in either $100 \mathrm{ml}$ medium in $250 \mathrm{ml}$ conical flasks or $500 \mathrm{ml}$ medium in $2-1$ conical flasks. Incubation was at $30^{\circ} \mathrm{C}$ in an orbital shaker ( 250 r.p.m.).

Bacterial growth was measured turbidimetrically at $600 \mathrm{~nm}$ in an SP 500 spectrophotometer (Pye Unicam), using $1 \mathrm{ml}$ cuvettes.

Harvesting and preparation of cell-free extracts. Bacteria were harvested in the mid-exponential phase $\left(\mathrm{OD}_{600} 0.3\right.$ to 0.8 ) by centrifugation at $23000 \mathrm{~g}$ for $10 \mathrm{~min}$ at $4{ }^{\circ} \mathrm{C}$, washed twice in $100 \mathrm{mM}-\mathrm{KH}_{2} \mathrm{PO}_{4} / \mathrm{K}_{2} \mathrm{HPO}_{4}$ buffer $(\mathrm{pH} 7.0)$ and resuspended in fresh buffer to about one-twentieth of the original culture volume. Bacteria were disrupted by sonication (MSE sonicator, $150 \mathrm{~W}, 6 \times 15 \mathrm{~s}, 0^{\circ} \mathrm{C}$ ) and centrifuged at $10000 \mathrm{~g}$ for $10 \mathrm{~min}$ at $4^{\circ} \mathrm{C}$ to give a cell-free extract.

Determination of acetonitrile, acetamide, acetate and ammonia. Samples of growth medium $(2 \mathrm{ml})$ from cultures containing acetonitrile or acetamide were centrifuged for $1 \mathrm{~min}$ in a Microfuge (Beckman Instruments). A $100 \mu \mathrm{l}$ sample of the supernatant was mixed with $25 \mu \mathrm{l} 25 \mathrm{mM}$-propionic acid (as an internal standard) in $250 \mathrm{mM}-\mathrm{HCl}$ and a $2 \mu \mathrm{l}$ sample was injected into a model 204 gas chromatograph (Pye Unicam) equipped with a flame ionization detector and linked to a model CDPI integrator. A glass column $(1.5 \mathrm{~m} \times 4 \mathrm{~mm}$ i.d.) was packed with Porapak $\mathrm{Q}$ (Waters Associates), mesh $80-100$. The detector was at $250^{\circ} \mathrm{C}$, the column at $190^{\circ} \mathrm{C}$ and the injector at $210^{\circ} \mathrm{C}$. The carrier was $\mathrm{N}_{2}$ at $50 \mathrm{ml} \mathrm{min}^{-1}$. Quantitative measurements were obtained by comparison with a standard curve of known concentrations of the test compounds by their peak areas relative to that of the propionic acid internal standard. For ammonia analysis, $100 \mu \mathrm{l}$ of the sample was mixed with $0.5 \mathrm{ml}$ nitroprusside reagent and $0.5 \mathrm{ml}$ alkaline hypochlorite reagent was added (Fawcett \& Scott, 1960). After mixing, the solution was incubated at $35^{\circ} \mathrm{C}$ for $15 \mathrm{~min}$ and the absorbance measured at $570 \mathrm{~nm}$. $\mathrm{An} \mathrm{NH}_{4} \mathrm{Cl}$ solution was used as a standard.

Determination of nitrile hydratase and amidase activities. Acetamidase activity was routinely measured by colorimetric assay of the ammonia produced. In cases where amides were present which interfered with the colorimetric assay, activity was measured by GLC analysis of the acetate produced. Because acetamidase activity was lower than acetonitrile hydratase activity, the latter was measured by the sum of the initial rates of acetamide and acetate formation. The reaction mixture $(5$ to $10 \mathrm{ml})$ at $30^{\circ} \mathrm{C}$ contained $100 \mathrm{mM}-\mathrm{KH}_{2} \mathrm{PO}_{4} / \mathrm{K}_{2} \mathrm{HPO}_{4}$ buffer (pH 7.0), $20 \mathrm{mM}$ - or $6 \mathrm{mM}$-nitrile or amide as substrate and bacteria or cell-free extract. The reaction was initiated by addition of substrate. For GLC analysis of the reaction products of nitrile hydratase and amidase, $100 \mu 1$ samples of the reaction mixture were removed at intervals up to $30 \mathrm{~min}$ and added to $25 \mu \mathrm{l} 25 \mathrm{mM}$-propionic acid in $250 \mathrm{mM}-\mathrm{HCl}$. When intact bacteria were used they were removed by centrifugation for $1 \mathrm{~min}$ in a microfuge before assay of reaction products. The samples were stored at $-20^{\circ} \mathrm{C}$ until required and then assayed by GLC as described above, except that when amides were the substrate the column was at $210^{\circ} \mathrm{C}$ and the injector at $230^{\circ} \mathrm{C}$. Ammonia was assayed as described above.

Other assays. Protein in cell-free extracts was measured by the modified biuret method of Gornall et al. (1949). Where intact bacteria were used, activity was related to dry weight, obtained by drying $1 \mathrm{ml}$ samples for $15 \mathrm{~min}$ in a model 7910 microwave oven (Philips).

A standard curve relating optical density to dry weight was constructed.

Chemicals. Acetamide, acetonitrile, benzamide, benzoic acid and formamide were obtained from Sigma. Benzonitrile and acetic acid were obtained from BDH. Acetamide was recrystallized from hot ethanol. Wherever possible, all other reagents were of analytical grade. Glass-distilled water and acid-washed glassware were used throughout.

\section{RESULTS}

The ability of Nocardia rhodochrous LL100-21 to grow on an extensive range of nitriles, amides and acids, when they were supplied as the sole carbon and nitrogen, carbon or nitrogen sources, is shown in Tables 1, 2 and 3. Additionally thioacetamide, thiourea, methylcarbamate, glycinamide, cyanoacetamide and nicotinamide could only be used as the sole source of nitrogen.

It is clear that a range of simple aliphatic nitriles and amides could act as carbon and nitrogen sources, confirming and extending the data of Collins \& Knowles (1983). However, the 1-carbon compounds cyanide and formamide did not act as carbon sources although formamide served as 
Table 1. Comparison of nitriles as substrates, inducers and inhibitors of $N$. rhodochrous LL100-21 acetonitrile hydratase

Bacteria were grown on M-9 salts with ammonium salts omitted, plus trace metals. Growth substrates were added as indicated. To study inhibition of growth, $10 \mathrm{mM}$-succinate and $10 \mathrm{mM}-\mathrm{NH}_{4} \mathrm{Cl}$ were added as carbon and nitrogen sources.

\begin{tabular}{|c|c|c|c|c|c|c|c|}
\hline \multirow[b]{2}{*}{ Nitrile } & \multicolumn{2}{|c|}{$\begin{array}{l}\text { Growth } \\
\text { substrate* }\end{array}$} & \multirow[b]{2}{*}{$\begin{array}{l}\text { Growth } \\
\text { inhibitor } \dagger\end{array}$} & \multirow[b]{2}{*}{$\begin{array}{c}\text { Enzyme } \\
\text { substrate }\end{array}$} & \multicolumn{2}{|c|}{ Enzyme inducer $\ddagger$} & \multirow{2}{*}{$\begin{array}{l}\text { Percentage } \\
\text { enzyme } \\
\text { inhibition }\end{array}$} \\
\hline & $\mathrm{C}+\mathrm{N}$ & $\mathbf{N}$ & & & $\begin{array}{c}\text { Nitrile } \\
\text { hydratase }\end{array}$ & Amidase & \\
\hline $\mathrm{KCN}$ & - & - & ND & - & ND & ND & ND \\
\hline Acetonitrile & $+t+$ & $++t$ & - & ++ & $+t$ & $+t$ & - \\
\hline Propionitrile & +++ & +++ & - & + & +++ & +++ & - \\
\hline Butyronitrile & $++t$ & $++t$ & - & + & ++ & ++ & - \\
\hline Isobutyronitrile & ++ & ++ & - & - & ++ & ++ & - \\
\hline Valeronitrile & +++ & +++ & - & + & + & + & ND \\
\hline Acrylonitrile & - & $\begin{array}{c}++ \\
\text { LC }\end{array}$ & +++ & ++ & - & - & ND \\
\hline Methacrylonitrile & - & +++ & - & + & - & - & ND \\
\hline Malononitrile & - & - & $++t$ & + & ND & ND & ND \\
\hline Succinonitrile & - & + & - & + & - & - & ND \\
\hline Glutaronitrile & - & + & - & - & - & - & 50 \\
\hline Adiponitrile & - & + & - & - & - & - & 100 \\
\hline Fumaronitrile & - & - & +++ & - & ND & ND & 68 \\
\hline Lactonitrile & - & - & $++t$ & - & ND & ND & 100 \\
\hline Phenylacetonitrile & - & $\begin{array}{c}++ \\
\mathrm{LC}\end{array}$ & ND & ND & - & - & 59 \\
\hline Benzonitrile & $\begin{array}{l}++ \\
\text { LC }\end{array}$ & $\begin{array}{l}++ \\
\mathrm{LC}\end{array}$ & $+t+$ & - & - & - & 74 \\
\hline $\begin{array}{l}\mathrm{ND}, \text { Not determi } \\
*+++, \mathrm{OD}_{600} \\
\text { nly supported gro } \\
+-, \text { No inhibiti } \\
++++,++,\end{array}$ & $\begin{array}{l}\text { en sup } \\
600> \\
\text { Relati }\end{array}$ & ++ & $\begin{array}{l}D_{600}>1.0 \\
\text { ncentratior } \\
\text { h; }+++ \\
\text { cf. Tables }\end{array}$ & $\begin{array}{l}\text { less than } \\
\text { growth. } \\
\text { nd 5). }\end{array}$ & $\begin{array}{l}\mathrm{DD}_{600}>0 . \\
\mathrm{nM} ;-, \mathrm{nc}\end{array}$ & $\begin{array}{l}\text { but }<1.0 \\
\text { rowth. }\end{array}$ & $\operatorname{hin} 72 \mathrm{~h}$ \\
\hline
\end{tabular}

a nitrogen source. The unsaturated compounds acrylamide, methacrylamide, acrylonitrile and methacrylonitrile only supported growth as sources of nitrogen. The dinitriles succinonitrile and glutaronitrile only served as poor nitrogen sources, whereas fumaronitrile and malononitrile would not support growth when supplied as either carbon or nitrogen sources. Amides derived from dinitriles were only able to support growth when present as the nitrogen source, as were $\mathrm{N}$ substituted amides. Substitution with a sulphur group, as in thioacetamide, resulted in a loss of ability to act as a carbon source and the addition of a phenyl group (phenylacetamide), an iodo group (iodoacetamide) or a hydroxyl group (lactonitrile) prevented the compound from serving as a carbon or nitrogen source.

Some nitriles, amides or acids were added at $30 \mathrm{mM}$ to a medium containing $10 \mathrm{~mm}$-succinate and $10 \mathrm{mM}-\mathrm{NH}_{4} \mathrm{Cl}$ as the sources of carbon and nitrogen respectively. Under these conditions, some of them, including those which could be utilized as a sole carbon or nitrogen source, inhibited growth (Tables 1,2 and 3).

When acetamide was used as the sole source of carbon and nitrogen, it was utilized via conversion to ammonia and acetate over a period of $12 \mathrm{~h}$ during growth (Fig. $1 \mathrm{a}$ ) (cf. Collins \& Knowles, 1983). Under these conditions synthesis of both acetonitrile hydratase and acetamidase began almost immediately and ceased once there was no acetamide left in the medium (Fig. 1b). Growth terminated on depletion of acetate. In contrast, growth on acetonitrile resulted in the disappearance of substrate within $6 \mathrm{~h}$ after inoculation with the concomitant production of acetamide, which was utilized by conversion to acetate and ammonia during exponential growth (Fig. $2 a$ ). The specific activity of acetonitrile hydratase 
Table 2. Comparison of amides as substrates, inducers and inhibitors of N. rhodochrous LL100-21 acetamidase

Bacteria were grown on M-9 salts with ammonium salts omitted, plus trace metals. Growth substrates were added as indicated. To study inhibition of growth, $10 \mathrm{~mm}$-succinate and $10 \mathrm{mM}-\mathrm{NH}_{4} \mathrm{Cl}$ were added as carbon and nitrogen sources.

\begin{tabular}{|c|c|c|c|c|c|c|c|}
\hline \multirow[b]{2}{*}{ Amide } & \multicolumn{2}{|c|}{ 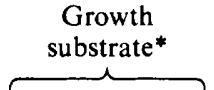 } & \multirow[b]{2}{*}{$\begin{array}{l}\text { Growth } \\
\text { inhibitor } \dagger\end{array}$} & \multirow[b]{2}{*}{$\begin{array}{l}\text { Enzyme } \\
\text { substrate }\end{array}$} & \multicolumn{2}{|c|}{ Enzyme inducer } & \multirow{2}{*}{$\begin{array}{c}\text { Percentage } \\
\text { enzyme } \\
\text { inhibition }\end{array}$} \\
\hline & $\overparen{C+N}$ & $\overline{\mathrm{N}}$ & & & $\begin{array}{l}\text { Nitrile } \\
\text { hydratase }\end{array}$ & Amidase & \\
\hline $\begin{array}{l}\text { Formamide } \\
\text { Acetamide } \\
\text { Propionamide } \\
\text { Butyramide } \\
\text { Isobutyramide }\end{array}$ & $\begin{array}{c}- \\
+++ \\
+++ \\
+++ \\
+++\end{array}$ & $\begin{array}{l}+++ \\
+++ \\
+++ \\
+++ \\
+++\end{array}$ & $\begin{array}{l}\text { ND } \\
- \\
- \\
-\end{array}$ & $\begin{array}{c}+ \\
++ \\
+++ \\
+ \\
+\end{array}$ & $\begin{array}{l}\text { ND } \\
++ \\
++ \\
+ \\
++\end{array}$ & $\begin{array}{c}+ \\
++ \\
+ \\
++ \\
++\end{array}$ & $\begin{array}{l}\text { ND } \\
- \\
- \\
- \\
-\end{array}$ \\
\hline Acrylamide & - & $\begin{array}{c}++ \\
\text { LC }\end{array}$ & +++ & +++ & + & + & ND \\
\hline Methacrylamide & - & +++ & - & + & ++ & +++ & ND \\
\hline Malonamide & - & + & - & ND & ND & ND & ND \\
\hline Succinamide & - & + & - & ND & ND & ND & ND \\
\hline Adipamide & - & + & - & ND & ND & ND & ND \\
\hline Lactamide & - & ++ & ND & ND & ND & ND & ND \\
\hline Urea & - & ++ & ND & + & ND & + & ND \\
\hline$N$-Methylformamide & - & $\begin{array}{c}+ \\
\text { sG }\end{array}$ & - & ND & ND & - & - \\
\hline$N$-Ethylformamide & - & $\begin{array}{c}+ \\
\text { SG }\end{array}$ & - & ND & ND & - & 7 \\
\hline$N$-Methylacetamide & - & + & - & ND & ND & - & - \\
\hline$N$-Ethylacetamide & - & + & - & ND & ND & + & - \\
\hline$N, N^{\prime}$-Dimethylacetamide & - & + & - & ND & ND & - & 16 \\
\hline Iodoacetamide & - & - & +++ & ND & ND & ND & 68 \\
\hline Phenylacetamide & - & - & ND & ND & ND & ND & ND \\
\hline Benzamide & $\begin{array}{l}++ \\
\text { LC }\end{array}$ & $\begin{array}{l}++ \\
\text { LC }\end{array}$ & - & - & - & - & ND \\
\hline
\end{tabular}

and acetamidase increased when acetamide appeared in the medium until it had been completely converted to acetate and ammonia, whereupon the activity of both enzymes disappeared rapidly (Fig. $2 b$ ). Exponential growth did not commence until the acetonitrile had been depleted from the medium, and growth terminated on depletion of acetate. During growth on either acetamide or acetonitrile, acetonitrile hydratase and acetamidase activities of intact bacteria exhibited similar patterns of induction, but the specific activity of acetamidase was approximately one-tenth that of acetonitrile hydratase.

In cell-free extracts, acetamidase activity had a broad $\mathrm{pH}$ optimum at 7.0 with $92 \%$ of maximal activity at $\mathrm{pH} 6.5$ and 7.5 . In contrast, acetonitrile hydratase had a sharp $\mathrm{pH}$ optimum at 7.0 with only $70 \%$ maximal activity at $\mathrm{pH} 6.5$ and 7.5 .

To study inducer specificity, extracts were prepared from bacteria grown on the nitriles and amides listed in Table 4 at a concentration of $20 \mathrm{~mm}$ or $6 \mathrm{~mm}$ and acetonitrile hydratase and acetamidase activities were measured with either $20 \mathrm{~mm}$-acetonitrile or $20 \mathrm{~mm}$-acetamide as substrate. All the aliphatic nitriles and amides that were effective inducers coinduced both enzymes, the specific activity of acetonitrile hydratase always being higher than that of acetamidase. Where an amide acted as an inducer of enzyme activity so did its corresponding nitrile, with the exception of the unsaturated amide acrylamide, and its methylated derivative, 

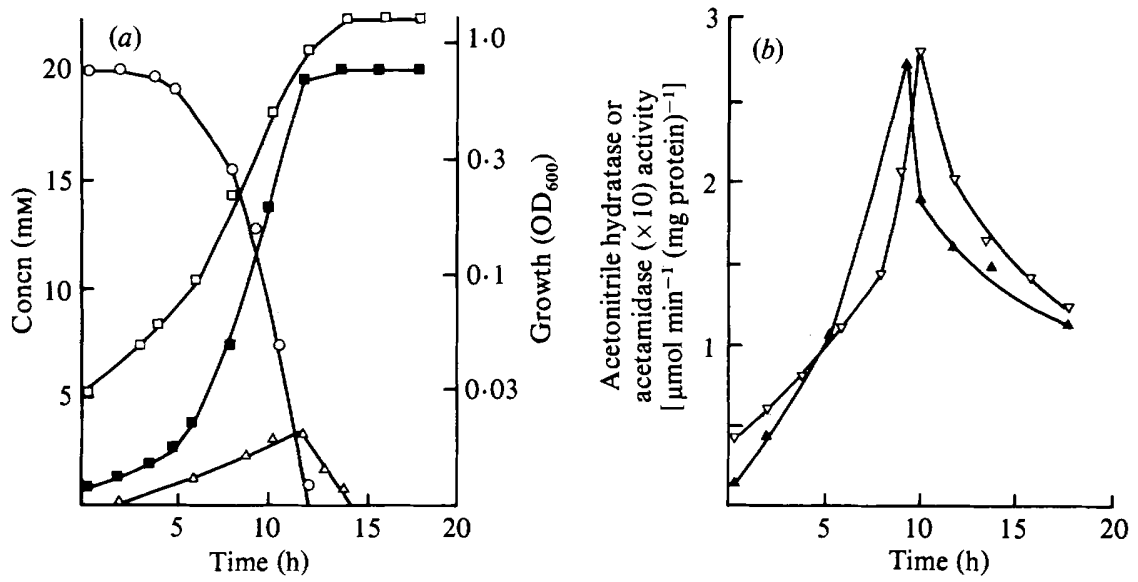

Fig. 1. Growth of $N$. rhodochrous on $20 \mathrm{~mm}$-acetamide. Samples $(2 \mathrm{ml})$ were aseptically removed from the cultures and $(a)$ the growth measured as $\mathrm{OD}_{600}(\square)$. The ammonia concentration in the medium ( $\square$ ) was measured colorimetrically, and the acetamide $(O)$ and acetate $(\triangle)$ concentrations by GLC. (b) Acetonitrile hydratase $(\boldsymbol{\Delta})$ and acetamidase $(\nabla)$ activities were measured in intact cells at various stages of growth as described in Methods using $20 \mathrm{~mm}$-acetonitrile and $20 \mathrm{MM}$-acetamide respectively as enzyme substrates.

\section{Table 3. Comparison of acids as growth substrates and inhibitors}

Bacteria were grown on $\mathbf{M}-9$ salts with ammonium salts omitted, plus trace metals. Acids were added as

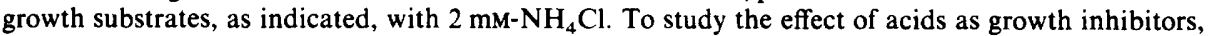
$10 \mathrm{~mm}$-succinate and $10 \mathrm{mM}-\mathrm{NH}_{4} \mathrm{Cl}$ were added as carbon and nitrogen sources.

$\begin{array}{lcc}\text { Acid } & \begin{array}{c}\text { Growth } \\ \text { substrate }\end{array} & \begin{array}{c}\text { Growth } \\ \text { inhibitort }\end{array} \\ \text { Acetate } & +++ & - \\ \text { Propionate } & +++ & - \\ \text { Butyrate } & +++ & - \\ \text { Isobutyrate } & +++ & - \\ \text { Valerate } & ++ & + \\ \text { Acrylate } & \text { LC } & +++ \\ \text { Methacrylate } & - & + \\ \text { Malonate } & - & +++ \\ \text { Succinate } & +++ & - \\ \text { Glutarate } & ++ & +++ \\ \text { Fumarate } & \text { LC } & \\ \text { Lactate } & + & +++ \\ \text { Phenylacetate } & +++ & - \\ \text { Benzoate } & - & +++\end{array}$

$*+++, \mathrm{OD}_{600}>1.0$ within $24 \mathrm{~h} ;++, \mathrm{OD}_{600}>1.0$ within $72 \mathrm{~h} ;+, \mathrm{OD}_{600}>0.05$ but $<1.0$ within $72 \mathrm{~h} ; \mathrm{LC}$, only supported growth when supplied at a concentration of less than $6 \mathrm{~mm}$; sG, slow growth; - , no growth.

$\dagger-$, No inhibition, $\mathrm{OD}_{600}>1.0$ within $24 \mathrm{~h} ;+, \mathrm{OD}_{600}>0.05$ but $<1.0$ within $72 \mathrm{~h} ;+++$, no growth.

methacrylamide, of which the corresponding nitriles acrylonitrile and methacrylonitrile were non-inducers.

The substrate specificities of acetonitrile hydratase and acetamidase were studied using cellfree extracts prepared from harvested bacteria that had been grown to the mid-exponential phase on acetonitrile or acetamide respectively (Table 5). Acetonitrile and acrylonitrile were 

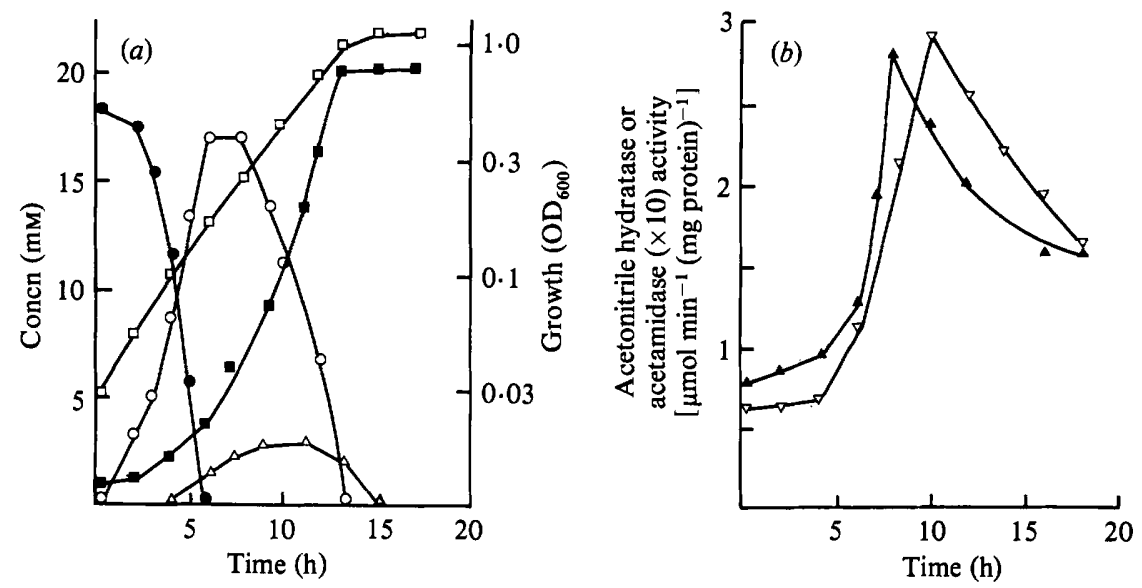

Fig. 2. Growth of $N$. rhodochrous on $20 \mathrm{~mm}$-acetonitrile. (a) Growth was measured as $\mathrm{OD}_{600}(\square)$. The ammonia concentration in the medium $(\square)$ was measured colorimetrically and the acetonitrile $(O)$, acetamide $(O)$ and acetate $(\triangle)$ concentrations by GLC. $(b)$ Acetonitrile hydratase $(\Delta)$ and acetamidase $(\nabla)$ activities were measured in intact cells using $20 \mathrm{~mm}$-acetonitrile or $20 \mathrm{~mm}$-acetamide as enzyme substrates.

\section{Table 4. Induction of enzymes exhibiting acetonitrile hydratase and acetamidase activities by growth on nitriles and amides}

Enzyme activities were measured at $30^{\circ} \mathrm{C}$ in cell-free extracts derived from bacteria that had been harvested in the mid-exponential growth phase $\left(\mathrm{OD}_{600} 0.4\right.$ to 0.7$)$. Acetonitrile hydratase activity was measured by the initial rate of formation of acetamide plus acetate, and acetamidase by the initial rate of formation of ammonia, using $20 \mathrm{~mm}$-acetonitrile and $20 \mathrm{~mm}$-acetamide as enzyme substrates, respectively. Enzyme activities, determined in six assays, are given in $\mu \mathrm{mol} \mathrm{min}^{-1}$ (mg protein) ${ }^{-1}$.

\begin{tabular}{|c|c|c|c|c|c|c|c|}
\hline & $\begin{array}{l}\text { Growth } \\
\text { concn } \\
(\mathrm{mM})\end{array}$ & $\begin{array}{c}\text { Nitrile } \\
\text { hydratase } \\
\text { activity }\end{array}$ & $\begin{array}{l}\text { Amidase } \\
\text { activity }\end{array}$ & $\begin{array}{l}\text { Growth } \\
\text { substrate }\end{array}$ & $\begin{array}{c}\text { Growth } \\
\text { concn } \\
(\mathrm{mM})\end{array}$ & $\begin{array}{c}\text { Nitrile } \\
\text { hydratase } \\
\text { activity }\end{array}$ & $\begin{array}{c}\text { Amidase } \\
\text { activity }\end{array}$ \\
\hline Acetonitrile & 20 & $2 \cdot 42$ & 0.22 & Acetamide & 20 & $2 \cdot 82$ & 0.26 \\
\hline Propionitrile & 20 & 6.42 & 0.43 & Propionamide & 20 & 1.06 & $0 \cdot 11$ \\
\hline Butyronitrile & 20 & 1.02 & $0 \cdot 24$ & Butyramide & 20 & 0.74 & 0.26 \\
\hline Isobutyronitrile & 20 & $1 \cdot 28$ & $0 \cdot 20$ & Isobutyramide & 20 & 1.61 & $0 \cdot 16$ \\
\hline Valeronitrile & 20 & 0.28 & 0.05 & Acrylamide & 20 & 0.42 & 0.08 \\
\hline Acrylonitrile & 6 & 0 & 0.01 & Methacrylamide & 20 & 1.79 & 0.64 \\
\hline Methacrylonitrile & 20 & $\begin{array}{l}0 \\
0\end{array}$ & $\begin{array}{l}0 \\
0\end{array}$ & Benzamide & 6 & 0 & 0 \\
\hline
\end{tabular}

rapidly hydrolysed by acetonitrile hydratase, whereas longer-chain saturated nitriles were only slowly hydrolysed. The branched isomer isobutyronitrile was not a substrate and the addition of a methyl group, as in methacrylonitrile, decreased the rate of hydrolysis. Substitution by a hydroxyl group, as in lactonitrile, caused a loss of ability to act as an enzyme substrate. Of the dinitriles studied, only the saturated 3- and 4-carbon compounds acted as substrates (Table 5).

Propionamide and acrylamide were excellent substrates for acetamidase, being hydrolysed two to three times faster than acetamide (Table 5). Although butyramide was as good an inducer as acetamide (Table 4), it was only slowly hydrolysed by acetamidase (Table 5).

The substrate specificities of the amidase activity induced by growth on the various acetamide analogues were also examined (Table 6). Although different levels of enzyme activity were induced during growth on the acetamide analogues, the patterns of the relative activities were similar to that for acetamidase, regardless of the growth substrate (Table 6), suggesting that in general the analogues were inducing the same enzyme. However, the high value obtained for the relative enzyme activity using formamide as the enzyme substrate after growth on formamide $(156 \%$, see Table 6$)$ suggests the induction of a specific formamidase. Similarly, growth on urea appeared to induce a urease. 
Table 5. Substrate specificity of acetonitrile hydratase and acetamidase induced by growth on acetonitrile and acetamide

A range of nitriles and amides, supplied at a concentration of $20 \mathrm{~mm}$, were examined as substrates for acetonitrile hydratase and acetamidase of extracts of bacteria induced by growth on $20 \mathrm{~mm}$-acetonitrile and $20 \mathrm{~mm}$-acetamide respectively. The numbers in parentheses are the specific activities [ $\mu \mathrm{mol} \mathrm{min}^{-1}$ (mg protein $)^{-1}$ ] determined in six assays.

$\begin{array}{lclc}\text { Substrate } & \begin{array}{c}\text { Percentage } \\ \text { activity }\end{array} & \text { Substrate } & \begin{array}{r}\text { Percentage } \\ \text { activity }\end{array} \\ \text { KCN } & 0 & \text { Formamide } & 12 \cdot 1 \\ \text { Acetonitrile } & 100 \cdot 0(2 \cdot 42) & \text { Acetamide } & 100 \cdot 0(0 \cdot 26) \\ \text { Propionitrile } & 3 \cdot 5 & \text { Propionamide } & 277 \cdot 0 \\ \text { Butyronitrile } & 1 \cdot 2 & \text { Butyramide } & 3.9 \\ \text { Isobutyronitrile } & 0 & \text { Isobutyramide } & 1 \cdot 4 \\ \text { Valeronitrile } & 4 \cdot 2 & \text { Acrylamide } & 195 \cdot 0 \\ \text { Acrylonitrile } & 67 \cdot 1 & \text { Methacrylamide } & 1 \cdot 6 \\ \text { Methacrylonitrile } & 10 \cdot 4 & \text { Benzamide } & 0 \\ \text { Malononitrile } & 9 \cdot 6 & \text { Urea } & 1 \cdot 2 \\ \text { Succinonitrile } & 10 \cdot 4 & & \\ \text { Glutaronitrile } & 0 & & \\ \text { Adiponitrile } & 0 & & \\ \text { Fumaronitrile } & 0 & & \\ \text { Lactonitrile } & 0 & & \\ \text { Benzonitrile } & 0 & & \end{array}$

Table 6. Substrate specificity of acetamidase induced by growth on various amides

The substrate specificity of acetamidase activity in cell-free extracts prepared from harvested bacteria grown on various acetamide analogues as carbon and/or nitrogen sources was examined. The amidase activities relative to that of acetamide $(100 \%)$ are given for each growth condition. The numbers in parentheses are the specific activities [ $\mu \mathrm{mol}$ ammonia formed $\mathrm{min}^{-1}$ (mg protein) ${ }^{-1}$ ] determined in six assays; ND, not determined.

Amide present during growth

Acetamide

Propionamide

Butyramide

Isobutyramide

Acrylamide

Formamide

Urea

Benzamide
Percentage hydrolysis of various substrates relative to that of acetamide

\begin{tabular}{|c|c|c|c|c|c|c|}
\hline $\begin{array}{l}\text { Propion- } \\
\text { amide }\end{array}$ & $\begin{array}{l}\text { Butyr- } \\
\text { amide }\end{array}$ & $\begin{array}{l}\text { Isobutyr- } \\
\text { amide }\end{array}$ & $\begin{array}{l}\text { Acryl- } \\
\text { amide }\end{array}$ & $\begin{array}{l}\text { Form- } \\
\text { amide }\end{array}$ & Urea & Benzamide \\
\hline $277 \cdot 0$ & 3.9 & $1 \cdot 4$ & $195 \cdot 0$ & $12 \cdot 1$ & $1 \cdot 2$ & 0 \\
\hline $302 \cdot 0$ & 1.6 & $1 \cdot 2$ & $260 \cdot 0$ & $13 \cdot 6$ & $1 \cdot 1$ & 0 \\
\hline $277 \cdot 0$ & $4 \cdot 1$ & $2 \cdot 1$ & $196 \cdot 0$ & $13 \cdot 3$ & $1 \cdot 4$ & 0 \\
\hline $235 \cdot 0$ & $2 \cdot 8$ & $2 \cdot 0$ & 183.0 & 10.7 & $2 \cdot 5$ & 0 \\
\hline $275 \cdot 0$ & $2 \cdot 8$ & $4 \cdot 4$ & $238 \cdot 0$ & $14 \cdot 6$ & $17 \cdot 3$ & 0 \\
\hline $238 \cdot 0$ & ND & ND & $251 \cdot 0$ & $156 \cdot 0$ & ND & ND \\
\hline $187 \cdot 0$ & ND & ND & $140 \cdot 0$ & ND & $706 \cdot 0$ & ND \\
\hline 0 & ND & ND & 0 & ND & ND & 0 \\
\hline
\end{tabular}

The aliphatic acetamidase induced by growth on the various acetamide analogues was unable to hydrolyse benzamide, confirming that benzamide is utilized by a separate enzyme system (Collins \& Knowles, 1983). Although present in intact cells, benzamidase activity could not be detected in cell-free extracts of bacteria grown on benzamide, as shown previously (Collins \& Knowles, 1983); there was a lack of activity over a wide $\mathrm{pH}$ range $(5 \cdot 6-8 \cdot 0)$. This could be due to lability of the enzyme or a requirement for a cofactor, as yet undetermined. 
Several amides and nitriles (at $50 \mathrm{~mm}$ ) were tested as possible inhibitors of acetamidase or acetonitrile hydratase activity by using cell-free extracts prepared from bacteria grown on acetamide or acetonitrile and with either acetamide or acetonitrile $(5 \mathrm{~mm})$ as the substrate for the assays. Many non-substrate amides and nitriles acted as enzyme inhibitors (Tables 1 and 2).

\section{DISCUSSION}

$N$. rhodochrous LL100-21 has been shown to utilize a range of aliphatic nitriles and amides as carbon and/or nitrogen sources via a nitrile hydratase and an amidase, both of which are inducible.

The ability of simple aliphatic amides to coinduce the hydratase and amidase enzymes at levels comparable to those resulting from growth on the corresponding nitriles, with the exception of propionitrile and propionamide, suggests that biosynthesis of these two enzymes is closely related, and strongly supports the hypothesis of Collins \& Knowles (1983) that they were formed from structural genes utilizing the same regulatory apparatus with the amide as the most likely inducer.

Clearly inducer and substrate specificities of the acetonitrile hydratase and acetamidase are quite distinct. Acetamide and propionamide, which were good substrates for acetamidase, were also good inducers of both the nitrile hydratase and amidase. However, butyramide, isobutyramide and methacrylamide were poor substrates but induced high levels of both enzymes, which could account for the good growth achieved on these compounds. Similarly, butyronitrile and isobutyronitrile acted as good inducers even though butyronitrile was only slowly hydrolysed by acetonitrile hydratase and enzyme activity with isobutyronitrile as substrate could not be detected. Propionitrile was an excellent inducer of both enzymes, the level of induction being two to three times that by acetonitrile.

Chain length appeared to be important in substrates for nitrile hydratase and amidase. Thus, acetonitrile was the best substrate for the hydratase enzyme, while propionitrile and butyronitrile with their increasing number of carbon atoms were hydrolysed progressively more slowly. In 4-carbon compounds the presence of the branched methyl group (i.e. in isobutyronitrile) prevented function as a substrate, while the presence of an unsaturated double bond (as in methacrylonitrile) enhanced the rate of hydration. However, acrylonitrile, of shorter chain length, was hydrolysed some seven times faster than methacrylonitrile.

Propionamide was the substrate most rapidly hydrolysed by acetamidase, amides of both longer and shorter chain length being hydrolysed far more slowly. The other 3-carbon amide, acrylamide, was also an extremely good substrate for the enzyme, but again, the derivative with a branched methyl group (methacrylamide) was a relatively poor substrate.

The presence of two nitrile groups in those compounds with a chain length of five carbons or more resulted in the ability to act as severe enzyme inhibitors. Inhibition of growth and amidase activity by iodoacetamide could be due to its known reaction with thiol groups rather than to its structural resemblance to acetamide.

The wide range of aliphatic amides that act as enzyme substrates for the inducible acetamidase of $N$. rhodochrous contrasts with the narrower range described for the amidase of Pseudomonas aeruginosa (Clarke, 1970). The relative substrate and inducer specificities also differ in the two bacteria, and no non-substrate inducers of $N$. rhodochrous acetamidase were found.

The inducible enzymes allowed $N$. rhodochrous to grow on a number of nitriles as the sole carbon and nitrogen source but the substrate spectrum was narrow in comparison to those of the inducible nitrile hydratase of Arthrobacter sp. J-1 (Asano et al., 1980, 1982), and the constitutive enzyme of Brevibacterium sp. R312 (Arnaud et al., 1977).

As yet, too little is known about the molecular properties of the amidases and, in particular, the nitrile hydratases of micro-organisms to explain these differences in specificities. Their clarification awaits purification and characterization of the enzymes involved.

This work was supported by a Studentship from the Science and Engineering Research Council to E.A.L. 


\section{REFERENCES}

Arnaud, A., Galzy, P. \& Jallageas, J.-C. (1976a). Amidase activity of some bacteria. Folia microbiologica (Praha) 21, 178-184.

ARnaud, A., Galzy, P. \& Jallageas, J.-C. (1976 b). Etude de l'activité nitrilasique de quelques bactéries. Revue des fermentations et des industries alimentaires 31, 39-44.

Arnaud, A., Galzy, P. \& Jallageas, J.-C. (1977). Etude de l'acétonitrilase d'une souche de Brevibacterium. Agricultural and Biological Chemistry 41, 21832191.

Asano, Y., Tani, Y. \& Yamada, H. (1980). A new enzyme 'nitrile hydratase' which degrades acetonitrile in combination with amidase. Agricultural and Biological Chemistry 44, 2251-2252.

Asano, Y., Fujishiro, K., Tani, Y. \& Yamada, H. (1982). Aliphatic nitrile hydratase from Arthrobacter sp. J-1. Purification and characterisation. Agricultural and Biological Chemistry 46, 1165-1174.

BAUCHOP, T. \& ElSDEN, S. R. (1960). The growth of micro-organisms in relation to their energy supply. Journal of General Microbiology 23, 457-469.

Clarke, P. H. (1970). The aliphatic amidases of Pseudomonas aeruginosa. Advances in Microbial Physiology 4, 179-222.

Clarke, P. H. (1980). The utilization of amides by microorganisms. In Microorganisms and Nitrogen Sources, pp. 537-562. Edited by J. W. Payne. New York: John Wiley \& Sons.

Collins, P. A. \& Knowles, C. J. (1983). The utilization of nitriles and amides by Nocardia rhodochrous. Journal of General Microbiology 129, 711-718.

DiGeronimo, M. J. \& ANTOINe, A. D. (1976).
Metabolism of acetonitrile and propionitrile by Nocardia rhodochrous LL100-21. Applied and Environmental Microbiology 31, 900-906.

FAwCETT, J. K. \& SCOTT, J. E. (1960). A rapid and precise method for the determination of urea. Journal of Clinical Pathology 13, 156-159.

Gornall, A. G., Bardawill, C. J. \& David, M. M. (1949). Determination of serum proteins by the biuret reaction. Journal of Biological Chemistry 177, 751-766.

HARPER, D. B. (1976). Purification and properties of an unusual nitrilase from Nocardia NCIB 11216. Biochemical Society Transactions 4, 502-504.

HARPER, D. B. (1977a). Microbial metabolism of aromatic nitriles. Enzymology of $\mathrm{C}-\mathrm{N}$ cleavage by Nocardia sp. (Rhodochrous group) NCIB 11216. Biochemical Journal 165, 309-319.

HARPER, D. B. (1977b). Fungal degradation of aromatic nitriles. Enzymology of $\mathrm{C}-\mathrm{N}$ cleavage by Fusarium solani. Biochemical Journal 167, 685-692.

HoOK, R. H. \& Robinson, W. G. (1964). Ricinine nitrilase. II. Purification and properties. Journal of Biological Chemistry 239, 4263-4267.

Jallageas, J.-C., Arnaud, A. \& Galzy, P. (1978). Etude l'acetamidase d'une souche de Brevibacterium. Journal of General and Applied Microbiology 24, 103114.

Miller, J. H. (1972). Experiments in Molecular Genetics, p. 431. Cold Spring Harbor, NY: Cold Spring Harbor Laboratory.

Robinson, W. G. \& Hook, R. H. (1964). Ricinine nitrilase. I. Reaction product and substrate specificity. Journal of Biological Chemistry 239, 42574262 . 